Journal of Advanced Research in Fluid Mechanics and Thermal Sciences

\title{
Investigation of the 16 Blades Pico Scale Breastshot Waterwheel Performance in Actual River Condition
}

\author{
Muhammad Rasyid Ramdhani ${ }^{1}$, Ridho Irwansyah ${ }^{1,}{ }^{*}$, Budiarso $^{1}$, Warjito ${ }^{1}$, Dendy Adanta ${ }^{2}$ \\ Department of Mechanical Engineering, Faculty of Engineering, Universitas Indonesia, 16424 Depok, Jawa Barat, Indonesia \\ Department of Mechanical Engineering, Faculty of Engineering, Universitas Sriwijaya, 30662 Indralaya, South Sumatera, Indonesia
}

\section{ARTICLE INFO}

Article history:

Received 29 December 2019

Received in revised form 16 March 2020

Accepted 18 March 2020

Available online 3 September 2020

Keywords:

Pico hydro; breastshot; waterwheel; remote area

\section{ABSTRACT}

Breastshot waterwheel are considered as one of solutions for electrification in remote areas in Indonesia. Since it has low investment and maintenance costs, as well as an uncomplicated manufacturing process. Analytically, the optimum performance of this turbine occurs at the ratio of tangential velocity of wheel with the upstream velocity of water is $0.25-0.35$ and numerically simulated the best efficiency is $62 \%$. However, there is no experimental study for 16 blades of breastshot waterwheel in pico scale in actual river condition. The experiment is carried out in actual conditions with a discharge of $0.09708 \mathrm{~m}^{3} / \mathrm{s}$ and head $0.26 \mathrm{~m}$. Based on results, the highest mechanical efficiency occurs at the ratio of tangential velocity of wheel with the upstream velocity of water is 0.83 , while for electrical efficiency it was found at the 0.95 . for $U$ / $\mathrm{C}$ compared to the reference, the results are quite far from optimal and for efficiency the result is slightly lower at $45 \%$.

Copyright @ 2020 PENERBIT AKADEMIA BARU - All rights reserved

\section{Introduction}

In 2019, more 4.16 million peoples of Indonesian in remote areas did not have access to electricity [1]. Pico hydro suitable to provide electricity in remote areas that do not have access to electricity because Indonesia has hydropower potential up to $19 \mathrm{GW}$ that spread on all provinces [2]. Furthermore, pico hydro has lower investment and operational costs compared to wind turbines and solar PV power plants [3]. Pico hydro is a green energy that exploits small streams to generate electricity under 5kW [4]. However, the problem faced in the use of pico hydro is river garbage such as twigs and plastic waste. River garbage makes the turbine cannot rotate properly [5]. Pico hydro type's waterwheel has a small effect on garbage [5]. Thus, pico hydroplants equipped with a waterwheel are one of the right solutions as a power plant for remote areas in Indonesia. Many researches have been made to optimize waterwheel at pico scale.

\footnotetext{
* Corresponding author.

E-mail address: ridho@eng.ui.ac.id 
Breastshot waterwheel are considered as one type of waterwheel suitable for remote areas in Indonesia [6]. Breastshot waterwheel are effective to be applied for low head conditions $(<5 \mathrm{~m})[5]$. Furthermore, breastshot waterwheel as an independent power plant in remote areas, exhibit several advantages: ease in irrigation construction, environmentally friendly, easily accessible manufacturing materials, relatively low investment costs and does not require complicated maintenance [7].

Many researches have been made to optimize the performance of breastshot waterwheel. Fundamental analytical has been done to get optimal geometry [8,9]. Analytical calculations were developed to identify the optimal form with the investment costs for installing waterwheels in remote areas $[10,11]$. The Computational fluid dynamics (CFD) method is used to analyse the shape of the blade and found the circle shape is the best [12]. The number of blades and the flow discharge of water are examined to get the relationship between these two things with the generated power and show that both factors affect the generated power [5]. The effect of variation blade height with inlet height on pico scale waterwheel is analysed using computational fluid dynamics (CFD) and found $h / L$ has significant influence on waterwheel performance [13]. Also found the best turbulence model for CFD simulation for pico hydro waterwheel is standard transitional SST turbulence model [14].

Based on literatures, a significant parameter affecting the performance of the waterwheel are tangential velocity and inflow velocity [15]. The tangential velocity of turbine $(U)$ is initial parameter determined where this will affect the diameter (D) size. The ratio of design tangential speed and theoretical velocity (based on energy line difference) should be between 0.2 and 0.35 (Sagebien wheel) [16]. This study conducted using a 16 blades breastshot turbine in the actual river conditions, aims to identify and compare the ratio between tangential velocity with upstream velocity of water and the highest electrical and mechanical generated power efficiency of breastshot waterwheel with previous study.

\section{Methodology}

\subsection{Analytic and Measurement Method}

Water discharge $(Q)$ and head $(h)$ were measured to determine potential power $\left(P_{\text {avai }}\right)$ available on the river. Available power $\left(P_{\text {avai }}\right)$ is calculated using Eq. (1).

$P_{\text {avai }}=\rho \cdot g \cdot Q \cdot h$

For $h$ was measured using length meter, while $Q$ is measured using the weir method. The shape of the weir used is a rectangular weir. Eq. (2) is used to calculate the $Q$ [17]. The measurement scheme is shown in Figure 1.

$Q=1,84 \cdot H^{3 / 2}(L-0,2 H)$

where $L$ is the length of the weir, $a$ is weir side length and $H$ is the height of water surface. 


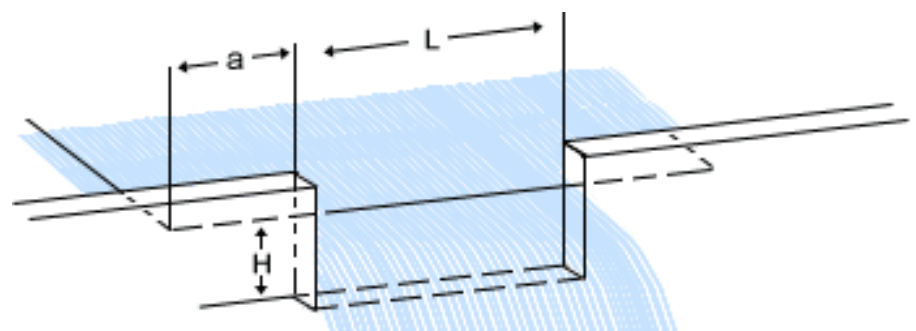

Fig. 1. Rectangular weir

To find mechanical power, the parameters that need to be measured is angular velocity $(\omega)$ and torque $(\tau)$ (see Eq. (3)).

$P_{\text {mech }}=\tau \cdot \omega$

The torque $(\tau)$ is calculated using force $(F)$. The force $(F)$ is measured using the Prony brake. The Prony brake scheme can be seen in Figure 2 . The force $(F)$ generated by the wheel can be calculated using Eq. (4).

$F=F_{2}-F_{1}$

where $F_{1}$ is a varying mass load, the mass load is given by adding a load of $2 \mathrm{~kg}$ in stages until the breastshot waterwheel stopped, in this study, the wheel stops at mass load of $60 \mathrm{~kg} ; F_{2}$ is the reading result from a force meter. The force meter was used has uncertainty $0.1 \mathrm{~g}$ with category reading. The result in force meter is still on kilogram $(\mathrm{kg})$, so we need multiply it with gravity to get force value, the gravity value used is $9.81 \mathrm{~m} / \mathrm{s}^{2}$. After getting the force $(F)$ value, the torque $(\tau)$ calculated using Eq. (5).

$\tau=F \cdot r$

where $r$ is the pulley radius.

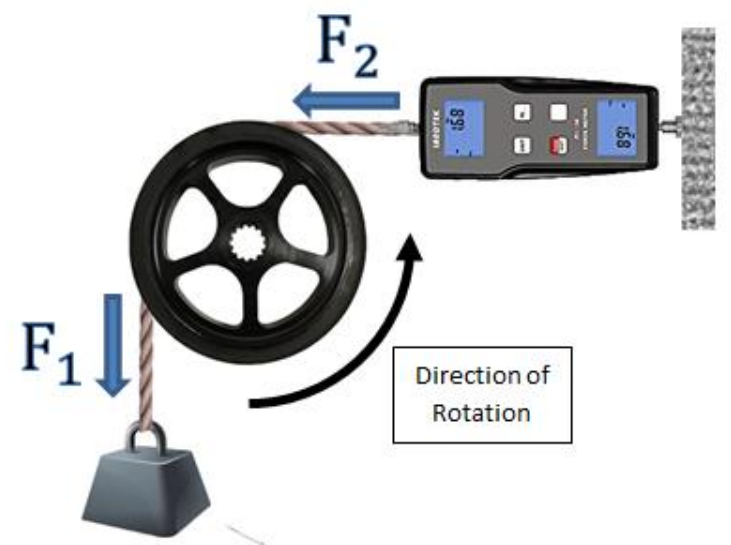

Fig. 2. The Prony brake scheme

Angular velocity $(\omega)$ can be calculated using Eq. (6).

$\omega=2 \cdot \pi \cdot n / 60$ 
where $n$ is the rotational speed (rpm) of wheel. The $n$ measured using commercial tachometer with uncertainty of 0.05 RPM with category full scale.

To find electrical power, the parameters that need to be measured is the voltage $(V)$ and current (I). Electrical power can be calculated using Eq. (7). Commercial multimeters with direct current (dc) specifications are used to measure the voltage $(V)$ and current $(I)$ generated by a DC generator. The commercial multimeter was used has uncertainty $0.7 \%$ for voltage and $2.2 \%$ for current with category full scale.

$P_{\text {elec }}=V \cdot I$

Electrical power measurements are done by connecting the generator with a load of $10 \mathrm{~W}\left(12 \mathrm{~V}_{\mathrm{dc}}\right)$ lamps. The lamps are installed in stages from 0 to 11 units (12 variations).

Thus, calculation of mechanical and electrical efficiency is done using Eq. (8) and Eq. (9).

$\eta_{\text {mech }}=\left(P_{\text {mech }} / P_{\text {avai }}\right) \cdot 100 \%$

$\eta_{\text {elec }}=\left(P_{\text {elec }} / P_{\text {avai }}\right) \cdot 100 \%$

To know the tangential velocity of wheel $(U)$ using Eq. (10).

$U=\frac{n}{60} \cdot D$

where $D$ is the diameter of the wheel.

Measurement of Upstream velocity of water $\left(C_{1}\right)$ is done by the buoy method, with two measurement poles within 10 meters. A buoy with a ballast is passed from the first measurement point to the second measurement point and then the travel time is recorded using a stopwatch. Five experiments were carried out and an average velocity was taken. The measurement scheme is shown in Figure 3. Upstream velocity of water $\left(C_{1}\right)$ can be calculated using Eq. (11).

$C_{1}=l / t$

where $l$ is distance between two poles, $t$ is times.

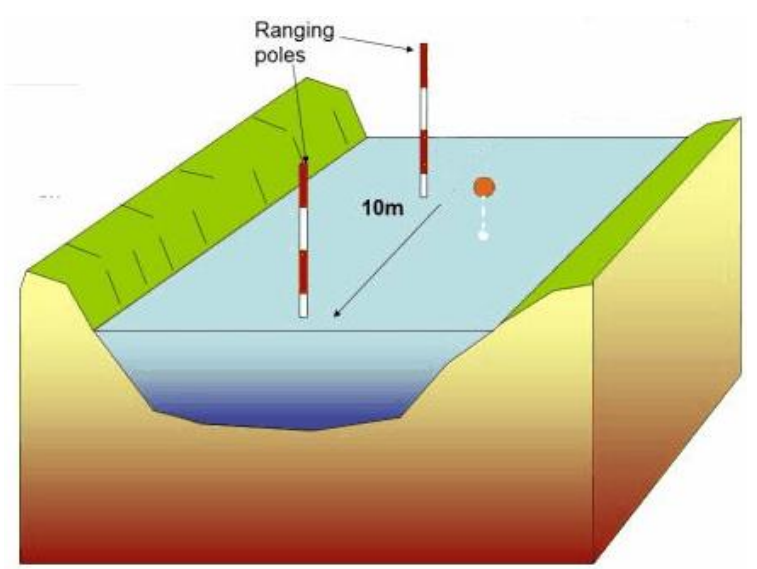

Fig. 3. Upstream river velocity measurement using buoy method 


\subsection{Breastshot Waterwheel Design}

Breastshot waterwheel with 16 buckets were used with a diameter of 1.2 meters. The detailed dimensions of the breastshot waterwheel are shown in Figure 4(a) and Figure 4(b). The weight of the waterwheel is $26 \mathrm{~kg}$, the material uses a $0.2 \mathrm{~mm}$ steel plate. 16 blades were chosen because of lower manufacturing costs.

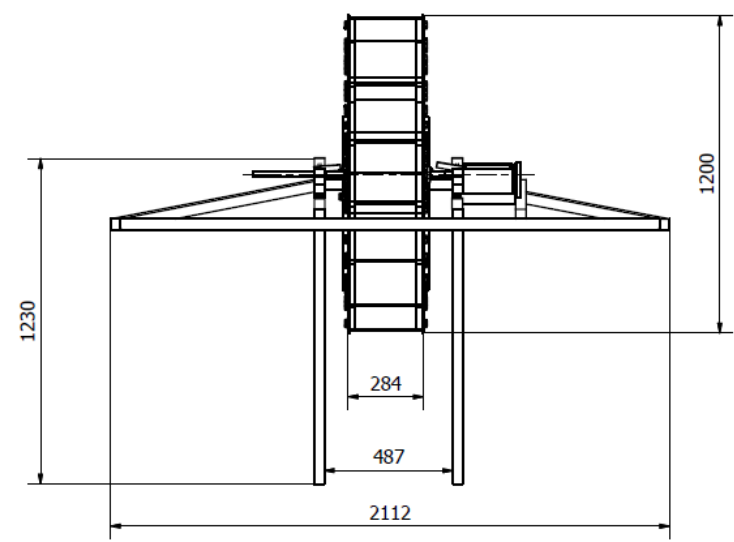

(a) Front view

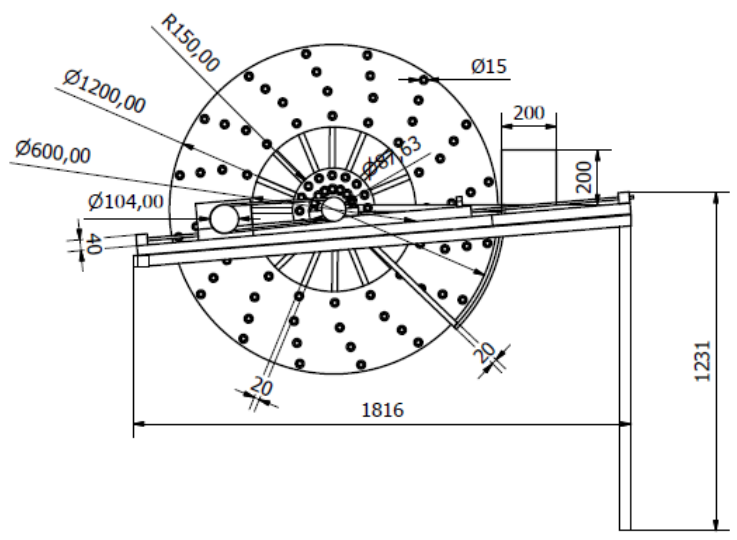

(b) side view

Fig. 4. Breastshot waterwheel detailed dimension

The breastshot waterwheel holder scheme is shown in Figure 5.

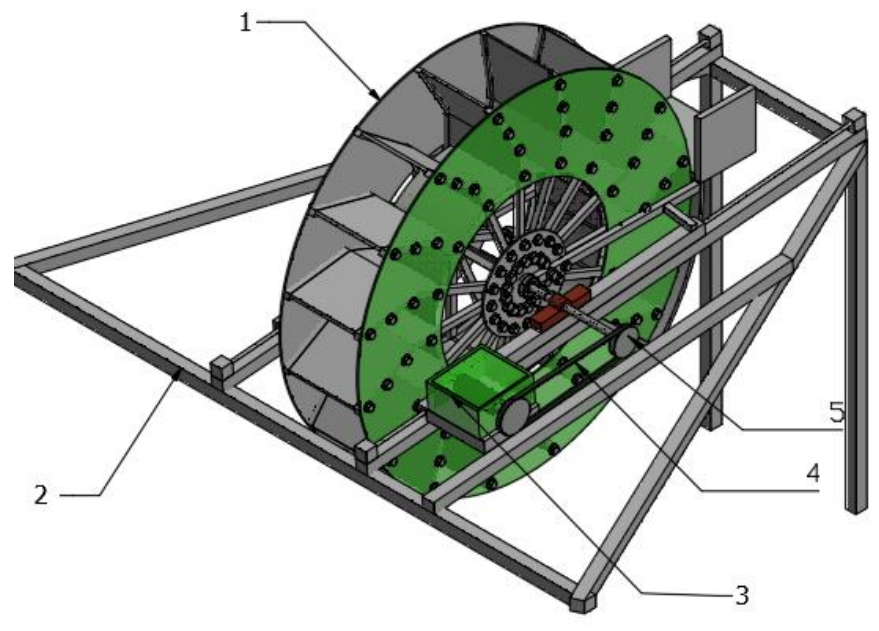

Information:

1. Breastshot Waterwheel

2. Frame

3. Generator

4. V-belt

5. Pulley

Fig. 5. Isometry view of the breastshot waterwheel

\section{Results and Discussions}

\subsection{Potential Power of Water}

The results of the measurements of water discharge $(Q)$ in river using the rectangular weir method are shown in Table 1.

Based on data in Table 1 and calculation using Eq. (2), the water discharge $(Q)$ in river is $0.09708 \mathrm{~m}^{3} / \mathrm{s}$. In the results obtained, the average of head $(h)$ is $0.26 \mathrm{~m}$. So, the potential power of water is 246.7 Watt.

And from the measurements using buoy method, the average upstream velocity of water $\left(C_{1}\right)$ is $0.909 \mathrm{~m} / \mathrm{s}$. 


\section{Table 1}

River discharge measurement result using rectangular weir method

\begin{tabular}{ll}
\hline Number of testing & Water height, $H$ \\
\hline 1 & $0.27 \mathrm{~m}$ \\
2 & $0.26 \mathrm{~m}$ \\
3 & $0.25 \mathrm{~m}$ \\
4 & $0.25 \mathrm{~m}$ \\
5 & $0.26 \mathrm{~m}$ \\
Average & $0.26 \mathrm{~m}$ \\
\hline
\end{tabular}

\subsection{Performance of Breastshot Waterwheel}

To find out the mechanical power of the breastshot waterwheel, the test was carried out 30 times from a mass load of $0 \mathrm{~kg}$ to $60 \mathrm{~kg}$. Based on measurements, the torque $(\tau)$ increases when adding load over $48 \mathrm{~kg}$ but the wheel rotation $(n)$ decreases. Table 2 are the results of these measurements. Based on Table 2, the highest efficiency mechanics $\left(\eta_{\text {mech }}\right.$ ) of the breastshot waterwheel is $45.72 \%$ $\left(P_{\text {mech }}\right.$ of $\left.112.79 \mathrm{Watt}\right)$ at wheel rotation $(n)$ of $13.8 \mathrm{rpm}$ with a torque of $78.01 \mathrm{~N} \cdot \mathrm{m}$.

\section{Table 2}

Mechanical power test summary

\begin{tabular}{llllll}
\hline $\begin{array}{l}\text { Testing } \\
\text { no. }\end{array}$ & $\begin{array}{l}\text { Wheel } \\
\text { rotation, } n\end{array}$ & Torque, $\tau$ & $\begin{array}{l}\text { Tangential } \\
\text { Velocity }(U), m / s\end{array}$ & $\begin{array}{l}\text { Mechanical } \\
\text { power, } P_{\text {mech }}\end{array}$ & $\begin{array}{l}\text { Mechanic } \\
\text { efficiency, } \eta_{\text {mech }}\end{array}$ \\
\hline 1 & $40.90 \mathrm{rpm}$ & $0.00 \mathrm{~N} \cdot \mathrm{m}$ & 2.57 & 0.00 Watt & $0.00 \%$ \\
2 & $39.10 \mathrm{rpm}$ & $11.48 \mathrm{~N} \cdot \mathrm{m}$ & 2.45 & 46.98 Watt & $18.98 \%$ \\
3 & $37.12 \mathrm{rpm}$ & $17.57 \mathrm{~N} \cdot \mathrm{m}$ & 2.33 & 68.27 Watt & $27.57 \%$ \\
4 & $35.20 \mathrm{rpm}$ & $21.45 \mathrm{~N} \cdot \mathrm{m}$ & 2.21 & 79.04 Watt & $31.92 \%$ \\
5 & $33.30 \mathrm{rpm}$ & $24.47 \mathrm{~N} \cdot \mathrm{m}$ & 2.09 & 85.29 Watt & $34.45 \%$ \\
$\ldots$ & $\ldots$ & $\ldots$ & $\ldots$ & $\ldots$ & $\ldots$ \\
23 & $14.86 \mathrm{rpm}$ & $71.11 \mathrm{~N} \cdot \mathrm{m}$ & 0.93 & 110.70 Watt & $44.87 \%$ \\
24 & $14.34 \mathrm{rpm}$ & $73.91 \mathrm{~N} \cdot \mathrm{m}$ & 0.90 & 111.04 Watt & $45.01 \%$ \\
25 & $13.8 \mathrm{rpm}$ & $78.01 \mathrm{~N} \cdot \mathrm{m}$ & 0.86 & 112.79 Watt & $45.72 \%$ \\
26 & $13.26 \mathrm{rpm}$ & $77.69 \mathrm{~N} \cdot \mathrm{m}$ & 0.83 & 107.92 Watt & $43.74 \%$ \\
27 & $12.8 \mathrm{rpm}$ & $77.58 \mathrm{~N} \cdot \mathrm{m}$ & 0.80 & 104.04 Watt & $42.17 \%$ \\
$\ldots$ & $\ldots$ & $\ldots$ & $\ldots$ & $\ldots$ & $\ldots$ \\
31 & $0.00 \mathrm{rpm}$ & $76.92 \mathrm{~N} \cdot \mathrm{m}$ & 0 & 0.00 Watt & $0.00 \%$ \\
\hline
\end{tabular}

The results of electrical power measurements are shown in Table 3. Based on Table 3, the more load is added, the more electricity is generated. Voltage $(V)$ increasing when adding a lamp load up to 10 , but more than 10 the resulting current $(I)$ will be significantly reduced. Consequently, the reduced current $(I)$ causes the electric power generated to decrease. The highest electrical efficiency $\left(\eta_{\text {elec }}\right)$ of $4.61 \%$ is achieved with 10 lamp loads with a voltage of $34.48 \mathrm{~V}_{\mathrm{dc}}$ and a current $(I)$ of $0.33 \mathrm{~A}$. 
Table 3

Electrical power test summary

\begin{tabular}{lllllll}
\hline $\begin{array}{l}\text { Load } \\
\text { no. }\end{array}$ & Voltage, $V$ & Current, $I$ & $\begin{array}{l}\text { Generator } \\
\text { rotation, } n_{\text {gen }}\end{array}$ & $\begin{array}{l}\text { Wheel } \\
\text { rotation, } n\end{array}$ & $\begin{array}{l}\text { Electric power, } \\
P_{\text {elec }}\end{array}$ & $\begin{array}{l}\text { Electric } \\
\text { efficiency, } \eta_{\text {elec }}\end{array}$ \\
\hline 0 & $70.10 \mathrm{~V}_{\mathrm{dc}}$ & $0.00 \mathrm{~A}$ & $1084.00 \mathrm{rpm}$ & $40.9 \mathrm{rpm}$ & 0.00 Watt & $0.00 \%$ \\
1 & $7.45 \mathrm{~V}_{\mathrm{dc}}$ & $0.55 \mathrm{~A}$ & $959.90 \mathrm{rpm}$ & $36.2 \mathrm{rpm}$ & $4.10 \mathrm{Watt}$ & $1.66 \%$ \\
2 & $9.60 \mathrm{~V}_{\mathrm{dc}}$ & $0.44 \mathrm{~A}$ & $902.20 \mathrm{rpm}$ & $34.0 \mathrm{rpm}$ & $4.22 \mathrm{Watt}$ & $1.71 \%$ \\
3 & $15.07 \mathrm{~V}_{\mathrm{dc}}$ & $0.39 \mathrm{~A}$ & $823.90 \mathrm{rpm}$ & $31.0 \mathrm{rpm}$ & $5.88 \mathrm{Watt}$ & $2.38 \%$ \\
4 & $21.89 \mathrm{~V}_{\mathrm{dc}}$ & $0.36 \mathrm{~A}$ & $757.30 \mathrm{rpm}$ & $28.5 \mathrm{rpm}$ & 7.88 Watt & $3.19 \%$ \\
5 & $25.76 \mathrm{~V}_{\mathrm{dc}}$ & $0.34 \mathrm{~A}$ & $697.00 \mathrm{rpm}$ & $26.2 \mathrm{rpm}$ & 8.76 Watt & $3.55 \%$ \\
6 & $24.52 \mathrm{~V}_{\mathrm{dc}}$ & $0.37 \mathrm{~A}$ & $606.10 \mathrm{rpm}$ & $22.8 \mathrm{rpm}$ & 9.07 Watt & $3.68 \%$ \\
7 & $27.65 \mathrm{~V}_{\mathrm{dc}}$ & $0.35 \mathrm{~A}$ & $528.80 \mathrm{rpm}$ & $19.9 \mathrm{rpm}$ & 9.68 Watt & $3.92 \%$ \\
8 & $32.32 \mathrm{~V}_{\mathrm{dc}}$ & $0.34 \mathrm{~A}$ & $478.80 \mathrm{rpm}$ & $18.0 \mathrm{rpm}$ & 10.99 Watt & $4.45 \%$ \\
9 & $31.50 \mathrm{~V}_{\mathrm{dc}}$ & $0.34 \mathrm{~A}$ & $416.70 \mathrm{rpm}$ & $15.7 \mathrm{rpm}$ & 10.71 Watt & $4.34 \%$ \\
10 & $34.48 \mathrm{~V}_{\mathrm{dc}}$ & $0.33 \mathrm{~A}$ & $321.10 \mathrm{rpm}$ & $12.1 \mathrm{rpm}$ & $11.38 \mathrm{Watt}$ & $4.61 \%$ \\
11 & $41.60 \mathrm{~V}_{\mathrm{dc}}$ & $0.27 \mathrm{~A}$ & $274.00 \mathrm{rpm}$ & $10.3 \mathrm{rpm}$ & 11.23 Watt & $4.55 \%$ \\
\hline
\end{tabular}

\subsection{Discussions}

Comparison of experimental results with previous studies conducted by Quaranta et al., [5] in Table 4.

Table 4

Comparation with previous study for 16 blades breastshot by Quaranta

\begin{tabular}{llllll}
\hline No & $\mathrm{Q}, \mathrm{m}^{3} / \mathrm{s}$ & $\frac{H}{D}$ & Torque, $N m$ & $\mathrm{~N}, \frac{\mathrm{Rad}}{\mathrm{s}}$ & efficiency, $\eta_{16}$ \\
\hline 1 & 0.05 & 0.197 & 160 & 0.78 & $62 \%$ \\
2 & 0.06 & 0.218 & 199 & 0.79 & $58 \%$ \\
3 & 0.07 & 0.248 & 216 & 0.89 & $53 \%$ \\
4 & 0.097 & 0.216 & 76.92 & 1.43 & $45 \%$ \\
\hline
\end{tabular}

In this comparison, this study has smaller efficiency results, seen from Table 4, with the same number of blades, increasing the number of discharges will reduce efficiency. In this study the torque obtained is smaller because the smaller diameter can be seen from the Head per Diameter (H / D) and in actual conditions in the river there are many streams of water that are not completely captured by the turbine due to poor channel design.

Figure 6 show the relationship between the ratio of tangential velocity of wheel $(U)$ and the upstream velocity of water $\left(C_{1}\right)$ to the mechanical and electrical efficiency of the breastshot waterwheel. Based on Figure 6 , the highest $\eta_{\text {mech }}$ occurs at the $\mathrm{U} / \mathrm{C}_{1}$ of 0.83 , while for $\eta_{\text {elec }}$ it was found at the $\mathrm{U} / \mathrm{C}_{1}$ of 0.95 .

The $U / C_{1}$ results are quite different from Sagebien's, which is around $0.25-0.33$, the shape of the breastshot turbine is not optimal for capturing energy efficiently under very small discharge and head conditions, so it is not recommended to use breastshot turbine in river flow conditions that have discharge and small head, from the turbine selection graph (Figure 7) the best turbine in this condition is Archimedes [16].

Although the efficiency results are relatively low, breastshot waterwheel technology is easily understood and easily manufactured by people in remote areas of Indonesia. 


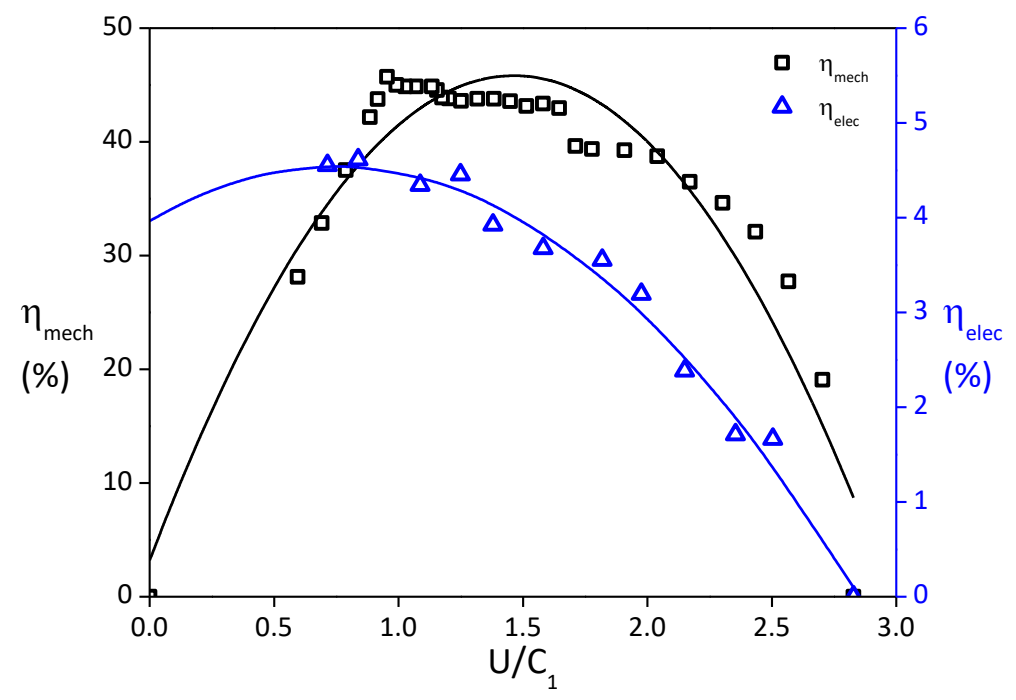

Fig. 6. Relationship of $\mathrm{U} / \mathrm{C}_{1}$ to $\eta_{\text {mech }}$ and $\eta_{\text {elec }}$ of the breastshot waterwheel

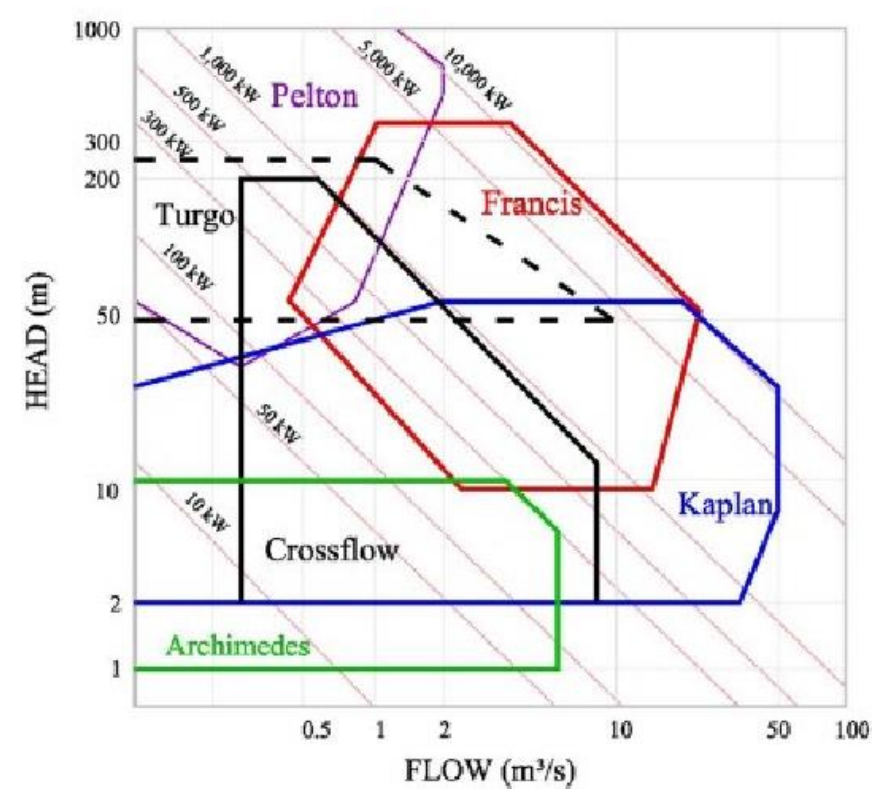

Fig. 7. Turbine Selection, Head vs Flowrate

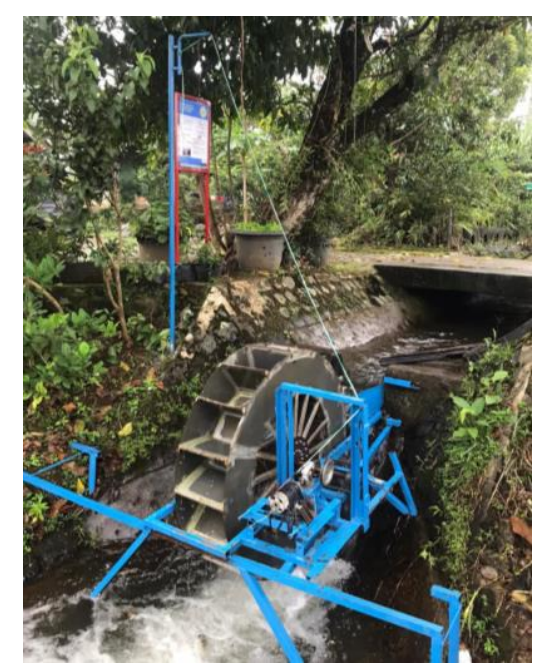

Fig. 8. Experiment documentation 


\section{Conclusions}

Based on the results, the performance of 16 blades breastshot waterwheel in discharge of $0.09708 \mathrm{~m}^{3} / \mathrm{s}$ and head of $0.26 \mathrm{~m}$ were: for the highest $\eta_{\text {mech }}$ occurs at the $\mathrm{U} / \mathrm{C}_{1}$ of 0.83 , while for $\eta_{\text {elec }}$ it was found at the $\mathrm{U} / \mathrm{C}_{1}$ of 0.95 . and has a mechanical efficiency of $45 \%$, slightly lower compared to studies conducted by Quaranta et al., [5]. Can be concluded from the comparation result, increasing the discharge with same number of blades (16 blades) causes reduction in performance efficiency and it is proven that the breastshot waterwheel does not produce optimal efficiency at a discharge below $0.1 \mathrm{~m}^{3} / \mathrm{s}$ and the head below $1 \mathrm{~m}$. In further studies it is recommended to be able to test different number of blades with more discharge and head variations.

\section{Acknowledgement}

This work was supported by Directorate of Research and Community Service (DRPM) Universitas Indonesia with grant No: NKB-0467/UN2.R3.1/HKP.05.00/2019.

\section{References}

[1] EBTKE, Humas. "Rasio Elektrifikasi 99.9\% Tahun 2019." Energi Baru Terbarukan dan Konservasi Energi (EBTKE), April 27, 2018. http://ebtke.esdm.go.id/post/2018/04/27/1945/menuju.rasio.elektrifikasi.99.persen.pada.2019.

[2] ESDM, Kementerian Energi dan Sumber Daya Mineral. "Rasio Elektrifikasi Indonesia." ESDM, 2017.

[3] Permana, Nicko Yoga. "STATISTIK EBTKE 2016 - Kementerian ESDM Republik Indonesia." Energi Baru Terbarukan dan Konservasi Energi (EBTKE), March 2017. http://ebtke.esdm.go.id/post/2017/03/07/1583/statistik.ebtke.2016.

[4] Basar, M. F., A. Ahmad, N. Hasim, and K. Sopian. "Introduction to the pico hydro power and the status of implementation in Malaysia." In 2011 IEEE Student Conference on Research and Development, pp. 283-288. IEEE, 2011. https://doi.org/10.1109/SCOReD.2011.6148751

[5] Quaranta, Emanuele, and Roberto Revelli. "Hydraulic behavior and performance of breastshot water wheels for different numbers of blades." Journal of Hydraulic Engineering 143, no. 1 (2017): 04016072. https://doi.org/10.1061/(ASCE)HY.1943-7900.0001229

[6] Adanta, Dendy, and Aji P. Prakoso. "The effect of bucketnumber on breastshot waterwheel performance." In IOP Conference Series: Earth and Environmental Science, vol. 105, no. 1, p. 012031. IOP Publishing Ltd., 2018. https://doi.org/10.1088/1755-1315/105/1/012031

[7] Ho-Yan, Bryan Patrick. "Design of a low head pico hydro turbine for rural electrification in Cameroon." PhD diss., The University of Guelph, 2012.

[8] Tevata, Anurat, and Chainarong Inprasit. "The effect of paddle number and immersed radius ratio on water wheel performance." Energy Procedia 9 (2011): 359-365.

https://doi.org/10.1016/i.egypro.2011.09.039

[9] Müller, G., and Christian Wolter. "The breastshot waterwheel: design and model tests." In Proceedings of the Institution of Civil Engineers-Engineering Sustainability, vol. 157, no. 4, pp. 203-211. Thomas Telford Ltd, 2004. https://doi.org/10.1680/ensu.2004.157.4.203

[10] Zaman, Ayesha, and Taslima Khan. "Design of a water wheel for a low head micro hydropower system." Journal Basic Science And Technology 1, no. 3 (2012): 1-6.

[11] Yelguntwar, Praful, Pranay Bhange, Yogesh Lilhare, and Ankit Bahadure. "Design, fabrication \& testing of a waterwheel for power generation in an open channel flow." International Journal of Research in Engineering \& Advanced Technology 2 (2014).

[12] Quaranta, Emanuele, and Roberto Revelli. "CFD simulations to optimize the blade design of water wheels." Drinking Water Engineering and Science 10, no. 1 (2017): 27. https://doi.org/10.5194/dwes-10-27-2017

[13] Adanta, Dendy, Sanjaya BS Nasution, and Muhamad Agil Fadhel Kurnianto. "The effect of blade height and inlet height in a straight-blade undershot waterwheel turbine by computational method." CFD Letters 11, no. 12 (2019): 66-73.

[14] Siswantara, Ahmad Indra, Budiarso, Aji Putro Prakoso, Gun Gun R. Gunadi, Warjito, and Dendy Adanta. "Assessment of turbulence model for cross-flow pico hydro turbine numerical simulation." CFD Letters 10, no. 2 (2018): 38-48. 
[15] Müller, Gerald, and Klemens Kauppert. "Performance characteristics of water wheels." Journal of Hydraulic Research 42, no. 5 (2004): 451-460. https://doi.org/10.1080/00221686.2004.9641215

[16] Quaranta, Emanuele, and Gerald Müller. "Sagebien and Zuppinger water wheels for very low head hydropower applications." Journal of Hydraulic Research 56, no. 4 (2018): 526-536. https://doi.org/10.1080/00221686.2017.1397556

[17] Bengtson, Harlan. "CE-086 Sharp Crested Weirs for Open Channel Flow Measurement." PDH Star (2019): 1-38. 